\title{
ROTATIONAL STABILITY OF DIFFERENT HIP REVISION SYSTEMS
}

\author{
M. Thomsen ${ }^{1}$, E. Jakubowitz ${ }^{2}$ \\ ${ }^{1}$ Mittelbaden Clinics Baden-Baden, Trauma and Orthopaedic Surgery Units, Baden-Baden, Germany \\ ${ }^{2}$ Laboratory of Biomechanics and Implant Research, University of Heidelberg, Department of Orthopaedics, Schlierbacher \\ Heidelberg, Germany
}

The authors present an experimental investigation that compares the primary rotational fixation of 4 revision stems.

Methods: Each stem was implanted into 4 synthetic femora. Micromotion of stem and bone was measured at defined sites under torque application. Femoral neck osteotomy and AAOS type I and III defects were simulated by reproducible saw lines.

Results: Up to a type I defect, all implants are capable of bridging the substance loss in a rotationally stable manner. The relative movements show a dependence both on the bone defect and on implant design. Even within the basic design types clear differences $(\mathrm{p}<0.0001)$ are partially observable. Major differences were seen in type III defects. Whereas the conical stem designs had the ability to bridge the extensive defect the cylindric shapes showed no rotationally stability.

Conclusion: As the major fixation area the femoral isthmus plays a decisive role for all tested stems. Due to enormous and partly selective load transmission of the conical stems the cylindrical designs is good for type I defects. In case of an extensive substance loss the decision should be a conical implant.

Key words: hip revision systems, rotational stability.

\section{Introduction}

Revision hip replacements are complicated surgeries because the femoral quality is often reduced by large substance losses. Stem fixation in terms of a sufficient primary stability is therefore a great challenge for the orthopaedic surgeon.

These problems are predominantly counteracted with cementless long-stemmed revision implants in order to achieve a bridging of deficient structures and a bone remodeling. Relative micromotions at the implant-bone interface represent a quantitative measurement to determine the primary stability and the initial rotational stability can serve as a valuable indicator for successful integration and function of cementless prosthesis stems $[2,9]$. We compared the primary stability of 4 current revision stems with different design parameters with a well-established measuring device and a standardized in vitro comparison of the primary (torsional) stability of revision hip stems $[3-5,10-14]$.

\section{Methods}

We investigated the cylindrical Helios ${ }^{\circledR}$ stem (Biomet Germany GmbH, Berlin, Germany) and the Standard-Range-Of-Motion $®$-"Revision stem" (S-ROM®) (DePuy Orthopedics Inc., Warsaw, USA) which consists of a prosthesis module and metaphyseal sleeves. The Modular-RevisionProsthesis ${ }^{\circledR}$ (MRP®) (Peter Brehm, GmbH, Weisendorf, Germany) is conically shaped in longitudinal direction and exhibits, in cross section, a star shape formed by parabolic longitudinal grooves.
The same shape is the Wagner-Self-Locking stem (Wagner-SL®) (Zimmer Inc., Warsaw, USA) which is a monoblock and some kind of father of all revision stems. All components are made of a titanium wrought alloy (Fig. 1).

The study followed a standardized protocol developed for the characterization of revision prostheses from our working group [4]. The relative movement between stem and bone is measured on several levels to show the primary fixation under different AAOS defect model conditions.

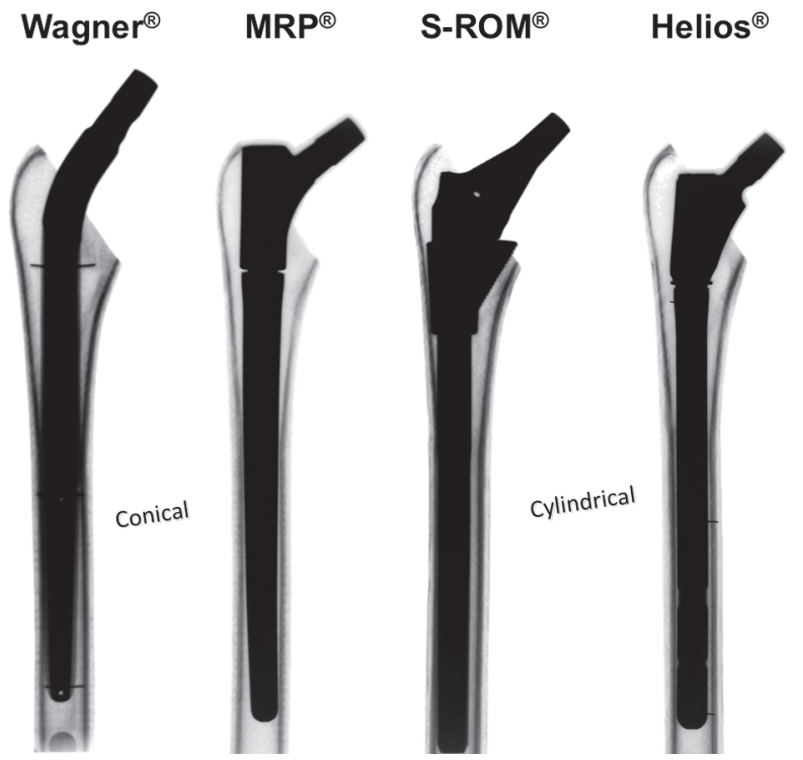

Fig. 1. Survey of the 4 revision hip stems 


\section{Results}

The Helios ${ }^{\circledR}$ implant exhibited a nearly constant relative movement from proximal to distal, except for the distal stem tip. In the isthmus, the closest contact with the femur. The MRP® prosthesis exhibited an extreme moment transfer in the distal isthmus, what suggests a very close contact between the stem and the femur. Relative to the points $\mathrm{P} 1$ and $\mathrm{P} 4$, it thus found its main fixation zone in the isthmus. Proximal and distal portions of the stem behaved similarly to those of the Helios ${ }^{\circledR}$ prosthesis. The main fixation of the $\mathrm{S}-\mathrm{ROM} \otimes$ stem was also located in the isthmus but the rotational moment transfer was the strongest in the proximal portion (site P2). On one side, a comparatively small metaphyseal movement of the stem was notable while on the other side, the tip of the stem exhibited a high value. The WagnerSL® stem, similar to MRP® prosthesis, showed a major fixation in the distal isthmus (P3) but demonstrated another fixation pattern. The bone and prosthesis curves diverged proximal and distal extreme, and particularly proximal registered a relative movement at $\Delta \mathrm{P} 1=20 \mathrm{mdeg} / \mathrm{Nm}$.

In the femur with AAOS type I defect the Helios ${ }^{\circledR}$ prosthesis qualitatively maintains its modus. Although the relative movements $\Delta \mathrm{P} 1, \Delta \mathrm{P} 2$ and $\Delta \mathrm{P} 3$ increase two-fold, the isthmus remains the main fixation zone (Fig. 2). The MRP ${ }^{\circledR}$ prosthesis clearly loses more stability than the Helios ${ }^{\circledR}$ stem. The S-ROM® prosthesis exhibits an almost unchanged fixation modus. Only at the tip of the stem (P4) a somewhat stronger decrease of the rotational stability occurs. The Wagner-SL $®$ stem shows hardly any changes, so that the modus even remains almost quantitatively comparable (Fig. 3). The S-ROM stem tip moves clearly more in the femur than those of other prostheses. At once, it anchors in the most stable way proximally. Except for the Helios ${ }^{\circledR}$ prosthesis, all prostheses maintain their main fixation region in the distal or proximal isthmus. The Wagner SL exhibits the significantly smallest relative movement in the distal isthmus (P3).

In the femur with the Wagner transfemoral approach and later with the AAOS type III defect, the sites P1 and P2 disappear due to the defect expansion. In the Helios ${ }^{\circledR}$ implant extreme movements appeared that were not measurable (Fig.4) with the applied measurement technique (out of range). The MRP $®$ prosthesis exhibits only a fraction of these movements. A prosthesis curve bending at the site P3 (not shown) indicates a firm interconnection in the remaining fixation section. The fixation modus of the S-ROM ${ }^{\circledR}$ prosthesis shows that the stem tip represents the main fixation point, although it cannot be described now as primarily stable. The Wagner-SL $®$ stem, on the other hand, shows a stable fixation (Fig. 5). Its main fixation lies now in the region of the stem tip while the farther proximally located bone is only negligibly forced into torsion.

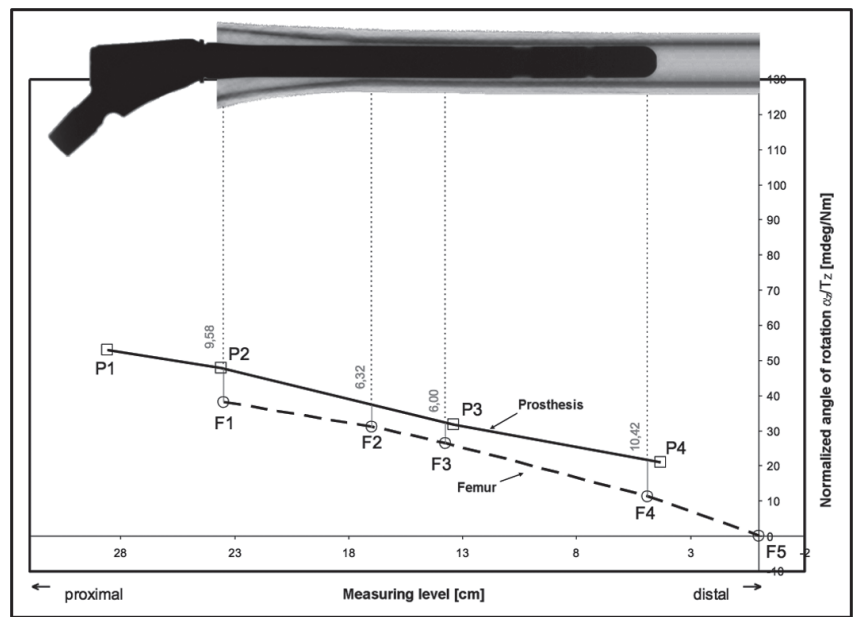

Fig. 2. The Helios shows with the AAOS I defect a good overall fixation

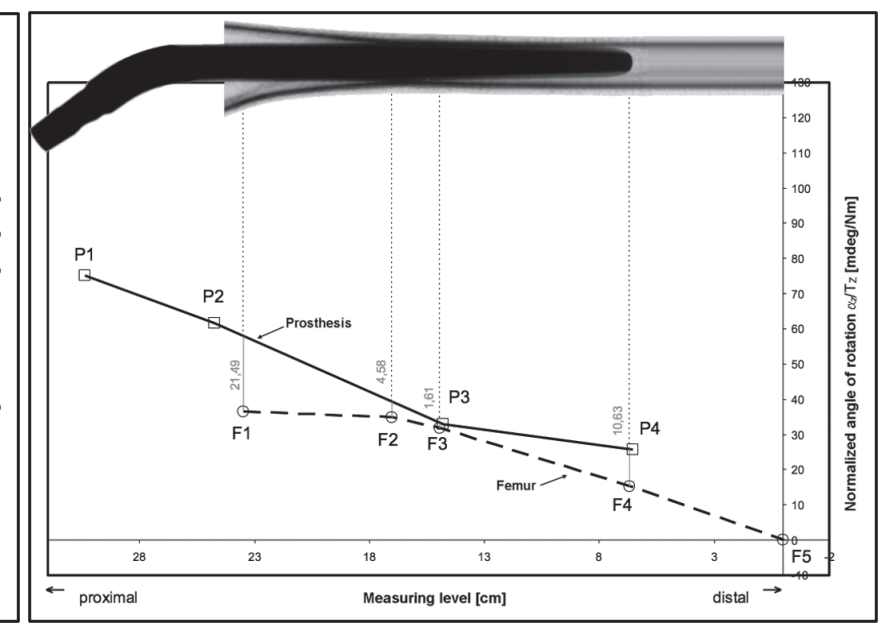

Fig. 3. Wagner stem with an AAOS I defect. It shows the extreme strong contact at the isthmus area with high primary fixation 


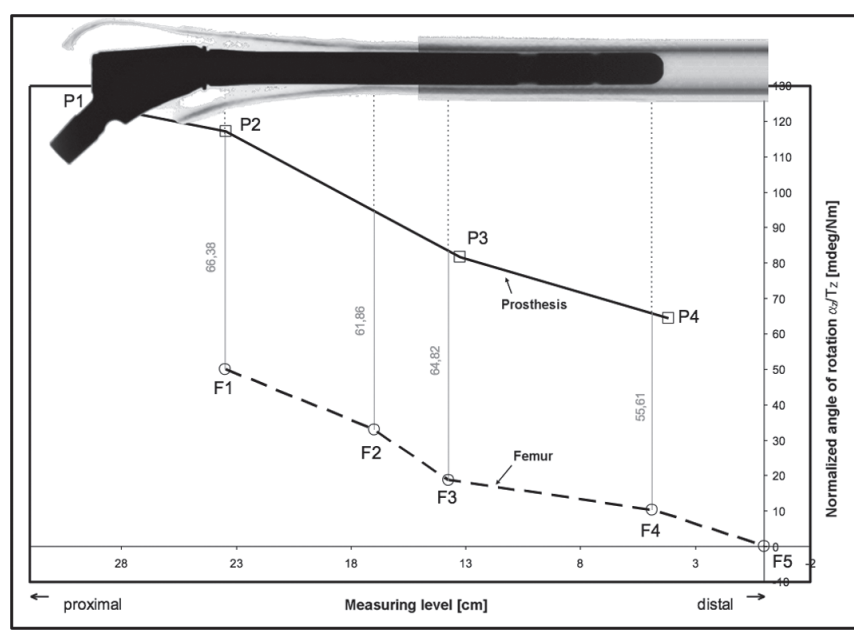

Fig. 4. The same approach with the Helios shows the limitation of this stem. This stem can not fixate anymore

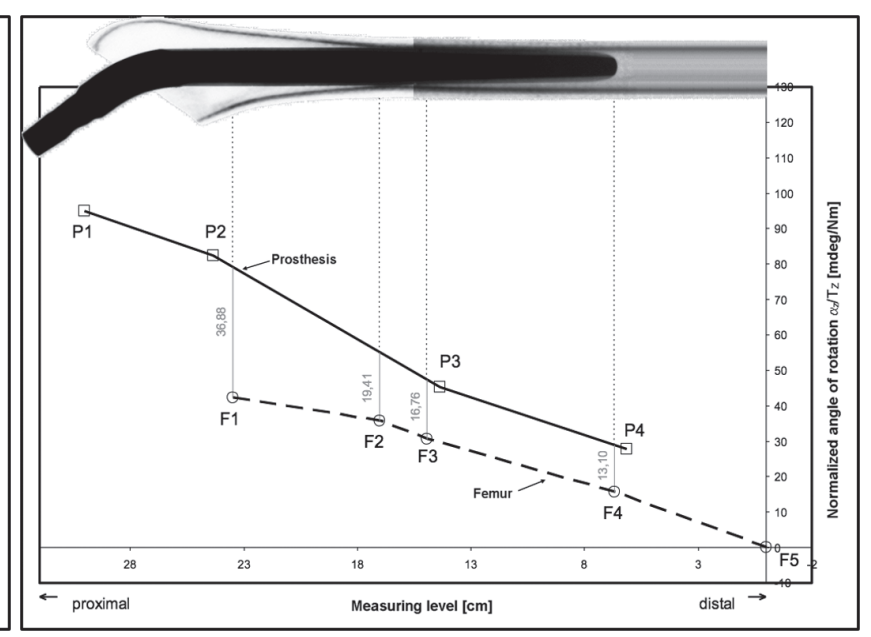

Fig. 5. With the transfemoral Wagner approach, the Wagner stems still shows a good fixation

fixation. The distal rotation stabilization is proven here up to the AAOS type I defect. Proximally the most primarily stable situation was reached by the $\mathrm{S}-\mathrm{ROM} \AA$ prosthesis, whereby the sleeve system presumably has advantages here. The segmental AAOS type I defect also shows that the implant suddenly becomes unstable and performs clearly larger relative movements. Though the stem cannot be described here as rotationally stable anymore, the distal tip anchors somewhat firmer than the distal isthmus region on the other side. The author of the conical stem shape Prof. Heinz Wagner often refers to the similarity of the Wagner-SL ${ }^{\circledR}$ prosthesis with Morse taper locks used in the mechanical engineering for joining of shafts $[15,16]$. In this fixation the conical stem is inserted into the medullary cavity milled with precise conical reamers. Thus a continuous contact with cortical bone should be established allowing the achievement of an equally distributed rotational stability [15]. This could only partially be confirmed in our tests. At $\Delta \mathrm{F} 3=1.42 \mathrm{mdeg} / \mathrm{Nm}$ in the undamaged femur and at $\triangle \mathrm{F} 3=1.61 \mathrm{mdeg} /$ $\mathrm{Nm}$ in the femur with the AAOS type I defect the implant exhibits a strong and precise main fixation in the distal isthmus. Similarly to D.C. Wirtz et al. [18] for the MRP® stem, H. Wagner [1987] and P.J. Warren et al. [17] also recommend the protection of a femur with reduced bone quality by tension wires during insertion of the Wagner-SL ${ }^{\circledR}$ stem. $\mathrm{H}$. Wagner $[15,16]$ also describes that a rapid bone consolidation is achieved proximally, which he attributes to the elastic bending deformation of the prosthesis. With regard to the relative movements investigated here it is possible to come to the conclusion that the prosthesis, at least rotationally, 
exerts mechanical stimulation on the proximal bone which could theoretically have a beneficial effect on the consolidation of damaged substance.

Up to an AAOS type I defect, all implants are capable of bridging a bone substance loss in a rotationally stable manner. Due to the large and highly localized load transmission of the conical implants MRP® and Wagner-SL $\circledR$, for example, the cylindrical designs would be advantageous for segmental or cavitary defects of the AAOS type I defect in conditions of an optimal "fit and fill". In case of an extensive substance loss, as with the AAOS type III defect, the decision should be made in favor of a conical or star-shaped implant. As the conical prosthesis stems find their main fixation region in the distal isthmus, it is preserved for them in such revision situation. With the cylindrical designs the proximal isthmus region, which is important for them, is lost. Thereby the femoral isthmus holds a key position both for the conically as well as the cylindrically designed prosthesis stems, be it in a different way.

\section{References}

1. Chandler HP, Ayres DK, Tan RC. et al. Revision total hip replacement using the S-ROM femoral component. Clin Orthop Relat Res. 1995; 319:130-140.

2. Gebauer D, Refior HJ, Haake M. Micromotions in the primary fixation of cementless femoral stem prostheses. Arch Orthop Trauma Surg. 1989; 108:300-307.

3. Görtz W, Nägerl UV, Nägerl H, Thomsen M. Spatial micromovements of uncemented femoral components after torsional loads. J Biomech Eng. 2002; 124:706-713.

4. Jakubowitz E, Seeger JB, Lee C, Heisel C, Kretzer J, Thomsen M. Primary rotational stability of cylindrical and conical revision hip stems as a function of femoral bone defects: An in vitro comparison. J Biomech. 2008; 41(14):3078-3084.

5. Jakubowitz E, Kinkel S, Nadorf J, Heisel C, Kretzer JP Thomsen M. The effect of multifilaments and monofilaments on cementless femoral revision hip components: an experimental study. Clin Biomech (Bristol, Avon). 2011 ;26(3):257-261.
6. Mumme T, Muller-Rath R, Weisskopf M. et al. The cementfree modular revision prosthesis MRP-hip revision stem prosthesis in clinical follow-up. Z Orthop Ihre Grenzgeb. 2004 142:314-321

7. Ohl MD, Whiteside LA, McCarthy DS, White SE. Torsional fixation of a modular femoral hip component. Clin Orthop Relat Res. 1993; 287:135-141.

8. Schuh A, Werber S, Holzwarth U, Zeiler G. Cementless modular hip revision arthroplasty using the MRP Titan revision stem: Outcome of 79 hips after an average of 4 years' follow-up. Arch Orthop Trauma Surg. 2004; 124:306-309.

9. Sugiyama H, Whiteside LA, Engh CA. Torsional fixation of the femoral component in total hip arthroplasty. The effect of surgical press-fit technique. Clin Orthop Relat Res. 1992; 275:187-193.

10. Thomsen $\mathrm{M}$, Aldinger $\mathrm{P}$, Gortz W. et al. The importance to generate robot-assisted milled cavities for total hip replacement. A comparative experimental study: manual versus robotic preparation. Unfallchirurg. 2001; 104: 692-699.

11. Thomsen M, Gortz W, Nagerl H. Charakterisierung moderner Huftendoprothesen. Z Orthop Ihre Grenzgeb. 1999; 137:A32.

12. Thomsen M, Kretzer JP, Heisel C, Lee C, Nadorf J, Jakubowitz E. Femorale Revisionsprothesen - Eine Analyse der Verankerung. Orthopäde. 2010; 39:623-630.

13. Thomsen M, Lee C. In-vitro rotational stability of cemented stem designs. In: Breusch SJ, Malchau H. (eds). The wellcemented total hip arthroplasty. Theory and practice. 1st ed. Berlin, Heidelberg, New York: Springer; 2005. p. 196-205.

14. Thomsen MN, Breusch SJ, Aldinger PR. et al. Roboticallymilled bone cavities: a comparison with hand-broaching in different types of cementless hip stems. Acta Orthop Scand. 2002; 73:379-385.

15. Wagner $H$, Wagner $M$. Konische Schaftverankerung zementfreier Huftprothesen - Primarimplantation und Prothesenwechsel. In: Morscher EW. (ed). Endoprothetik. 1st ed. Berlin, Heidelberg, New York: Springer; 1995. p. 278-288.

16. Wagner H. Femur revision prosthesis. Z Orthop Ihre Grenzgeb. 1993; 131:574-577.

17. Warren PJ, Thompson M, Fletcher MD. Transfemoral implantation of the Wagner SL stem. The abolition of subsidence and enhancement of osteotomy union rate using Dall-Miles cables. Arch Orthop Trauma Surg. 2002; 122:557-560.

18. Wirtz DC, Heller KD, Holzwarth U. et al. A modular femoral implant for uncemented stem revision THR. Int Orthop. 2000 24:134-138.

19. Wirtz DC. Modulare Schaftimplantate: Klinische Ergebnisse der MRP-Titanprothese. In: Thumler P, Forst R, Zeiler G. (eds). Modulare Revisionsendoprothetik des Huftgelenks. 1st ed. Berlin, Heidelberg, New York: Springer; 2005. p. 271-281.

\author{
AUTHOR'S INFORMATION: \\ Prof. Dr. Marc Thomsen \\ Chief Orthopaedic surgeon at Trauma and Orthopaedic Surgery Units - Baden-Baden Balg and Baden-Baden Annaberg \\ Mittelbaden Clinics Baden-Baden \\ e-mail: marc.thomsen@klinikum-mittelbaden.de
}

Received 28.11.2014 


\title{
РОТАЦИОННАЯ СТАБИЛЬНОСТЬ РАЗЛИЧНЫХ РЕВИЗИОННЫХ СИСТЕМ
}

\author{
М. Томсен ${ }^{1}$, Е. Якубович ${ }^{2}$
}

${ }^{1}$ Отделение травматологии и ортопедии Клиники Миттельбаден, г. Баден-Баден, Германия

2 Лаборатория биомеханики и имплантологических исследований, Гейдельбергский университет, кафедра ортопедии,

г. Гейдельберг, Германия

Цель - сравнить первичную ротационную стабильность четырех ревизионных бедренных компонентов.

Meтоды. Каждую из четырех ножек имплантировали в синтетические бедренные кости, после чего измеряли момент вращения, который вызывал микроподвижность между ножкой и костью в определенных участках. С помощью пилы были смоделированы воспроизводимые остеотомии шейки бедренной кости и дефекты I и III типа по классификации AAOS.

Результаты. До I типа дефекта включительно все имплантаты выдерживали потерю вещества кости и демонстрировали ротационную стабильность. Относительная нестабильность зависела как от типа костного дефекта, так и от конструкции имплантата. Даже между основными типами конструкций имелись четкие различия ( $<0,0001)$. Наибольшие различия были отмечены при III типе дефектов. В то время как конические бедренные компоненты были способны противостоять обширным дефектам, имплантаты цилиндрической формы не показывали ротационной стабильности.

Заключение. Главной областью фиксации для всех протестированных ножек является истмус канала бедренной кости. Ввиду того, что конические ножки передают на кость очень значительную и неравномерную нагрузку, при дефектах I типа предпочтительнее цилиндрические конструкции. В случае обширной потери костной ткани целесообразно использовать конический бедренный компонент.

Ключевые слова: ревизионные бедренные компоненты, ротационная стабильность.

\section{СВЯЗЬ С АВТОРАМИ:}

Томсен Марк - доктор медицины, профессор, главный ортопед отделения травматологии и ортопедии, Клиника Миттельбаден, Баден-Баден

e-mail: marc.thomsen@klinikum-mittelbaden.de 